\title{
Euro-MPs turn up the heat on energy projects
}

Munich. The European Parliament's committee on research, technological development and energy has begun an investigation into allegations that the European Commission has mishandled money intended for research into renewable energy sources.

The committee plans also to use the opportunity to raise with the commission the wider question of the lack of openness in the commission's procedures for allocating research money, which some claim leads to a climate of distrust.

The allegations focus on the Joule programme, which has been allocated ECU967 million (US\$1.3 billion) to distribute over five years. The commission has agreed to devote about 60 per cent of the programme's funds to projects concerned with renewable energy resources, such as solar and wind power. But only 40 per cent of the ECU191 million distributed in the first round in July went to renewable energy projects (see Nature 376, 628; 1995).

In a statement issued last week, the commission rejects claims that the views of outside experts were manipulated during the review process. Jean-Christophe Filori, a spokesman for the commission, says that there were not enough good renewable energy projects this time round. But he adds that the balance between renewable and conventional projects will be corrected during future funding rounds.

Filori claims that the commission has "absolutely no political wish to downgrade renewable energy in Europe". But members of the European Parliament (MEPs) are not satisfied with this reassurance. They argue and the commission acknowledges - that some of the renewable energy projects were downgraded from an initial rating after they had been assessed by two independent

\section{IMAGE UNAVAILABLE FOR COPYRIGHT REASONS}

Renewable energy: solar cells at Adrano, Sicily.

expert committees, one looking at the scientific merits and the other at the strategic merits of applications.

Nuala Ahern, a Green MEP for Ireland, says the commission has not yet provided a satisfactory explanation of why the grades had been changed. "The European commission sets the agenda and then moves the goal posts", she says.

The British, Greek and Irish members of the committee overseeing the Joule programme, which is made up of representatives from each European Union state and is invited to give its opinion on the final list of projects put forward by the commission, have also complained.

David Irving, for example, who is head of the Department of Trade and Industry's environment and energy technologies division, and the UK representative on the com-

$\vec{a}$ mittee, said in a letter to the commission that the United Kingdom was unable to $\frac{\bar{\sigma}}{\alpha}$ support the commission's proposed list,

"not because of misgivings over the 181 projects per se, but over the manner by which the list had been derived".

In particular, wrote Irving, the British delegation felt that "some kind of reexamination of the 'downgraded' projects was needed to reassure the research community about the fairness of procedures".

One of the three members of the Joule expert committee concerned with assessing the strategic aims of applications was Jört Schindler, manager of the Munich-based company Ludwig Bölkow Systemtechnik $\mathrm{GmbH}$. He says the experts were very unhappy that the gradings of applications were changed without consultation.

Filori denies that the programme has been manipulated. "In the fourth Framework programme there are a lot of very strict criteria to be applied to grant applications, in addition to scientific excellence, which are not widely understood", he says.

Alison Abbott

\section{Astronomers view 'tolerance' satellite with jaundiced eye}

Boston. Plans to launch a bright satellite to celebrate the proclamation by the United Nations of 1995 as the "Year of Tolerance" have brought protests from both the American Astronomical Society (AAS) and the International Astronomical Union (IAU).

According to current designs, the proposed satellite, known as the 'Star of Tolerance', would consist of two giant, reflective balloons, of 30-metre and 50-metre diameters respectively, linked by a $2-\mathrm{km}$ tether. The structure would circle the planet every two hours, and would remain in low Earth orbit for between 18 months and four years before burning up in the atmosphere.

Visible to the naked eye in the hours before and after sunset, the satellite is intended to remind those who see it to accept cultural difference both between and within communities. The venture is led by Nersi Razavi, a Paris businessman, and has already won the support of the United Nations Educational, Scientific and Cultural Organization (UNESCO).

A launch date has not yet been fixed, although the Russian space agency has offered to carry the balloon payload at a total mission cost of about $\$ 20$ million. "We're shooting for the end of 1996, but that depends on many factors, including money," says Serguei Lazarev, coordinator of the project for UNESCO. Various fund-raising options are being considered, including the idea of a 'world lottery'.

But astronomers hope to intervene before the project goes much further. "We applaud the worldwide recognition of world peace and tolerance of all peoples, but the proposed manner of communicating these ideas would seriously impair the science of optical astronomy all over the world," wrote Robert Milkey, executive officer of the AAS, on 29 August in a letter to Federico Mayor, UNESCO's director general.

"This is not the first time an idea like this has been raised," says Woody Sullivan, an astronomer at the University of Washington who is vice president of an IAU commission on protecting observatories from optical and radio interference and space debris.

In the late-1980s, for example, the French government backed a plan to orbit a $24-\mathrm{km}$ circumference band of reflective balloons, a so-called 'Ring of Light', to commemorate the 100th anniversary of the Eiffel Tower.

None of these plans has yet materialized, and Sullivan would like to keep it that way.

Patrick Crane, chairman of the AAS committee on light pollution, agrees. "Much pain could be avoided if the sponsors of these projects were to consult with astronomers ahead of time, so that we didn't go over the same lessons each and every time." The basic problem, he says, is that unlike the use of the radio spectrum, which is governed by the International Telecommunications Union, there are no regulations on space art or space advertising and no formal agencies equipped to deal with these questions.

UNESCO's Lazarev maintains that he has seen several letters from astronomers claiming that the level of brightness from the Star of Tolerance would not disturb scientific observations, although he accepts that this position is far from unanimous. "The most important thing about this mission is the symbolic message," he says. "Otherwise, the project is entirely flexible. The design of the satellite can be changed, and its brightness adjusted, to make sure it doesn't contribute to space pollution."

Steve Nadis 